\title{
Differences of soil enzyme activities and its influencing factors under different flooding conditions in Ili Valley, Xinjiang
}

\author{
Zhang Yulu ${ }^{1,2}$, Cui Dong ${ }^{\text {Corresp.. } 1,2}$, Yang Haijun ${ }^{1,2,3}$, Nijat Kasim ${ }^{1}$ \\ ${ }^{1}$ College of Biology and Geography, Ili Normal University, Yining, lli Kazakh Autonomous Prefecture, China \\ 2 Institute of Resources and Ecology, Ili Normal University, Yining, Ili Kazakh Autonomous Prefecture, China \\ 3 Ministry of Education Key Laboratory of Vegetation Ecology, Institute of Grassland Science, Northeast Normal University, Changchun, China \\ Corresponding Author: Cui Dong \\ Email address: cuidongw@126.com
}

Background:Wetland is a special ecosystem formed by the interaction of land and water. The moisture content variation will greatly affect the function and structure of wetland internal system.

Method:In this paper, three kinds of wetlands with different flooding levels (Phragmites australis wetland(long-term flooding),Calamagrostis epigeios wetland(seasonal flooding) andDitch millet wetland(rarely flooded)) in Ili Valley of Xinjiang China was selected as research area. The changes of microbial biomass carbon, soil physical and chemical properties in wetlands were compared, and redundancy analysis was used to analyze the correlation between soil physical and chemical properties, microbial biomass carbon and enzyme activities (soil sucrase, catalase, amylase and urease). The differences of soil enzyme activities and its influencing factors under different flooding conditions in Ili Valley were studied and discussed.

Result:The results of this study were the following: (1) The activities of sucrase and amylase in rarely flooded wetlands and seasonally flooded wetlands were significantly higher than those in long-term flooded wetlands; the difference of catalase activity in seasonal flooded wetland was significant and the highest. (2) Redundancy analysis showed that soil organic carbon, dissolved organic carbon, total phosphorus and soil microbial biomass carbon had significant effects on soil enzyme activity $(p<0.05)$. (3)The correlation between soil organic carbon and the sucrase activity, total phosphorus and the catalase activity was the strongest; while soil organic carbon has a significant positive correlation with invertase, urease and amylase activity, with a slight influence on catalase activity. The results of this study showed that the content of organic carbon, total phosphorus and other soil fertility factors in the soil would be increased and the enzyme activity would be enhanced if the flooding degree was changed properly. 
1 Differences of Soil Enzyme Activities and Its Influencing

2 Factors under Different Flooding Conditions in Ili Valley,

3 Xinjiang

4

5

6

7

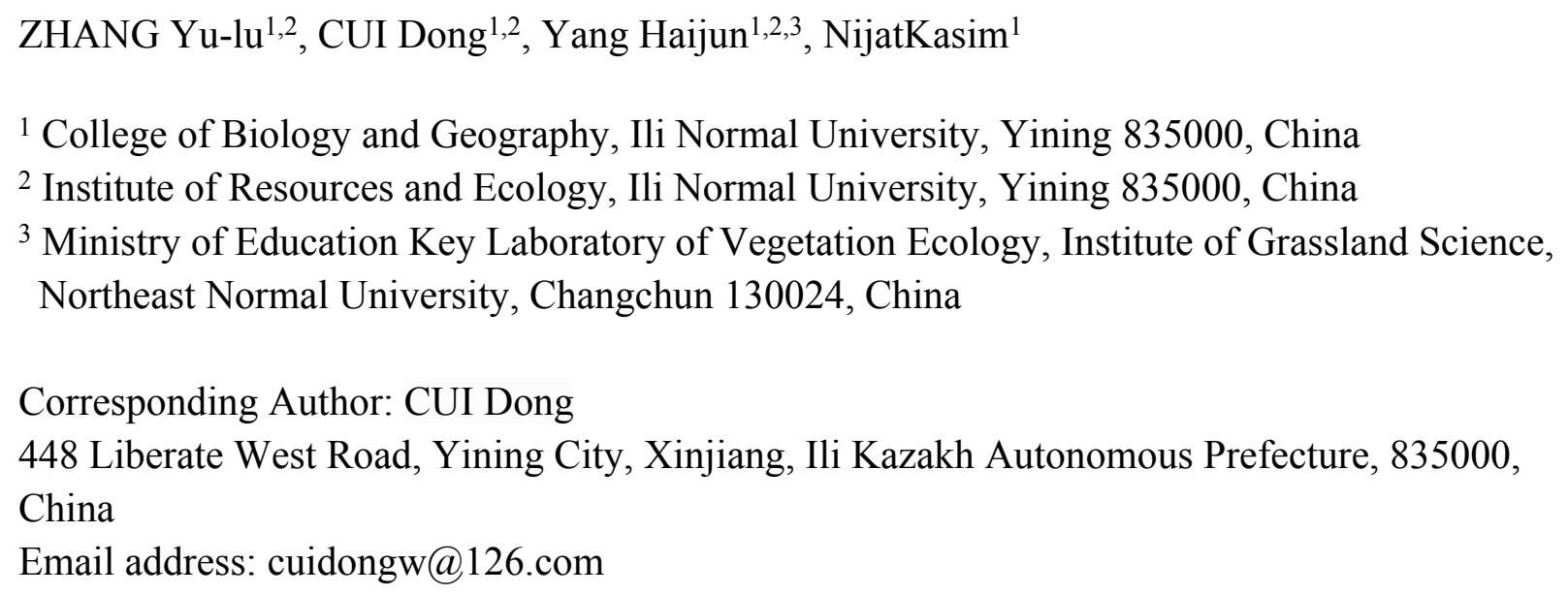

\section{Abstract}

Background: Wetland is a special ecosystem formed by the interaction of land and water. The moisture content variation will greatly affect the function and structure of wetland internal system.

Method: In this paper, three kinds of wetlands with different flooding levels (Phragmites australis wetland (long-term flooding), Calamagrostis epigeios wetland (seasonal flooding) and Ditch millet wetland (rarely flooded)) in Ili Valley of Xinjiang China was selected as research area. The changes of microbial biomass carbon, soil physical and chemical properties in wetlands were compared, and redundancy analysis was used to analyze the correlation between soil physical and chemical properties, microbial biomass carbon and enzyme activities (soil sucrase, catalase, amylase and urease). The differences of soil enzyme activities and its influencing factors under different flooding conditions in Ili Valley were studied and discussed.

Result: The results of this study were the following: (1) The activities of sucrase and amylase in rarely flooded wetlands and seasonally flooded wetlands were significantly higher than those in long-term flooded wetlands; the difference of catalase activity in seasonal flooded wetland was significant and the highest. (2) Redundancy analysis showed that soil organic carbon, dissolved organic carbon, total phosphorus and soil microbial biomass carbon had significant effects on soil enzyme activity $(p<0.05)$. (3)The correlation between soil organic carbon and the sucrase activity, total phosphorus and the catalase activity was the strongest; while soil organic carbon has a significant positive correlation with invertase, urease and amylase activity, with a slight influence on catalase activity. The results of this study showed that the content of organic carbon, total phosphorus and other soil fertility factors in the soil 


\section{Materials \& Methods}

\section{Site description} changed properly.

\section{Introduction} wetland protection in Ili Valley.

would be increased and the enzyme activity would be enhanced if the flooding degree was

Keywords: Wetland; flooding conditions; soil enzyme activity; soil physical and chemical properties; microbial biomass carbon.

Wetlands are ecological systems with unique biological characteristics, soil and hydrology (Jenkinson DS., 1991). Its soil is immersed in water, and there are many different kinds of animals, plants and microorganisms with wetland characteristics. So wetland is not only a natural landscape with affluent ecological diversity in nature, but also an important environment for human survival (Lu Xiaoyi, 2004; Garken Jumaken ette et al., 2018). According to research, water is an important environmental factor, which plays an important role in maintaining the stability of structure and function in wetland ecosystem and affecting the biogeochemical cycle in wetland (Yu Xianmin, 1999). Therefore, in recent years, the effects of water on wetland soil factors and plant growth have been studied widely. Studies have found that plants can adapt to the stress of different flooding environments by changing their height, the stem diameter, and population density (Tan Xuejie et al., 2006). Compared with natural exposed soil, the submerged environment promoted the growth and activity of soil microorganisms, enhanced the activity of the soil enzyme (liu Yajun et al., 2017). It can be seen that different water conditions have a profound influence on the growth and reproduction of wetland plants.

The Ili Valley belongs to the arid inland river basin wetland, and its total wetland area is about $2.4 \times 10^{5} \mathrm{~km}^{2}$. There are many types and wide distribution of wetlands in the valley. Because of its natural environmental conditions and special geographical location, Ili Valley has created a wetland landscape with abundant water resources and rich species. At present, Ili Valley is a key protected biodiversity area in China (Galkenjumaken Ett et al., 2014). In recent years, owing to human over-reclamation and the influence of natural factors, the degradation of most wetlands has become more and more serious, especially the fluctuation of water content. However, the change of water conditions will have a great impact on the process of soil carbon accumulation and decomposition (Wan Zhongmei, 2009). Besides, with the degradation of wetlands, the content of soil organic carbon decreased significantly, and the activity of soil enzymes also changed (Chen Yanxin, 2018). There are few reports on this aspect in the Ili Valley. This study takes Ili valley wetland with different flooding levels as the research object. It analyzes the change of soil enzyme activity of wetland under different flooding conditions, and it discusses the relationship between water and soil factors affecting the enzyme activity, which provided a theoretical basis for the study of the mechanism of soil water impact on soil and

PeerJ reviewing PDF | (2019:08:39997:1:2:NEW 3 Dec 2019) 
78

79

80

81

82

83

84

85

86

87

88

89

90

91

92

93

94

95

96

97

98

99

100

101

102

103

104

105

106

107

108

109

110

111

112

113

114

115

116

117

Ili River Valley is located in the northwest direction of Tian Shan Mountains in Xinjiang China, and surrounded by high mountains in the north, east and south, showing the natural geographical features of "three mountains with two valleys". It enjoys the reputation of "Wet Island in the western region" and "Jiang Nan beyond the Great Wall", and is the main transportation route of the ancient Silk Road.

In addition, the Ili Valley is situated at $80^{\circ} 09^{\prime} \mathrm{E}-84^{\circ} 56^{\prime} \mathrm{E}$ in the east longitude and $42^{\circ} 14^{\prime} \mathrm{N}$ $44^{\circ} 50^{\prime} \mathrm{N}$ in the North latitude, with an altitude of $530 \sim 1000 \mathrm{~m}$ and an area of $56,400 \mathrm{~km}^{2}$. Due to the excellent natural environment and unique geographical position of the Ili Valley, the water resources and mineral resources are quite abundant, and there are various species in the valley. The climate is warm and humid, belonging to the temperate continental climate, with a great temperature difference between day and night. The annual average temperature is $10.4{ }^{\circ} \mathrm{C}$, and the annual average sunshine hours are $2700 \sim 3000$ hours. The annual average precipitation is approximately $417.6 \mathrm{~mm}$, mainly concentrated in spring and summer, which is $60 \% \sim 70 \%$ of the annual precipitation. With the increase of altitude, the precipitation can be as high as $600 \mathrm{~mm}$ in mountainous areas, and the annual average evaporation is about $1260 \sim 1900 \mathrm{~mm}$, which is the wettest climate area in Xinjiang China.

The Ili River Valley mainly distributes forests, grasslands and meadows. The grassland soil types are mainly gray-calcium soils. The plant species are mostly perennial and cold-tolerant grasses; the forest soil is mainly taupe forest soil, and the tree species are mostly Xinjiang clouds. Cedar, snowy spruce, eucalyptus, etc (Yang Yuhai et al., 2010).

\section{Study site and sample collection}

The sampling sites were selected in Ili River floodplain wetland and Liberate Bridge National Wetland Park in Zhaosu County, as shown in figure 1. In September 2017, three kinds of wetland soils with different flooding degrees were collected in Wetland Park, i.e. Ditch millet wetland (DMW), Calamagrostis epigeios wetland (CEW) and Phragmitesaustralis wetland (PAW). Among them, DMW belongs to the rarely flooded habitat; CEW belongs to the seasonal flooded habitat, with a one-year flooding period of about 2 3 months; while PAW belongs to the long-term flooded habitat, with a one-year flooding period of about 10 months.

Three plots $(1 \mathrm{~m} \times 1 \mathrm{~m})$ were randomly set up in the selected sampling area. Firstly, in each wetland type, plant and its litter on the surface of the plot were removed with a shovel to obtain the three random soil profiles. Afterwards, soil samples of $0 \sim 10 \mathrm{~cm}, 10 \sim 20 \mathrm{~cm}, 20 \sim 30 \mathrm{~cm}$, $30 \sim 40 \mathrm{~cm}$ were collected from bottom to top, respectively. And the total of 36 soil samples were collected from three wetland types, the collected samples were sealed in plastic bags and brought back to the laboratory. The samples were divided into two parts, one of which was stored in a sealed bag and stored in a refrigerator for the determination of soil microbial biomass carbon and soil enzyme activity, and the other was placed in a bag and air-dried, ground, and passed through a $0.15 \mathrm{~mm}$ sieve to determine the physical and chemical properties of the soil.

\section{Figure.1}


118

119

120

121

122

123

124

125

126

127

128

129

130

131

132

133

134

135

136

137

138

139

140

141

142

143

144

145

146

147

148

149

150

151

152

153

154

155

156

157

\section{Analysis of soil properties}

\section{(1) Soil physical and chemical properties}

The content of soil organic carbon (SOC) was measured by a $\mathrm{K}_{2} \mathrm{CrO}_{7}-\mathrm{H}_{2} \mathrm{SO}_{4}$ oxidation procedure (Lu Rukun, 1999). The soil samples were boiled with perchloric acid and sulfuric acid. Afterwards, the total phosphorus (TP) content in soil was determined by colorimetry (Lu Rukun, 1999). The content of easily oxidized organic carbon (EOC) in soil can be obtained by putting potassium permanganate solution into soil sample and then colorimetric method (Blair et al., 1995). The content of dissolved organic carbon (DOC) was determined by colorimetry (Zhan Xinhua et al., 2002). It is known that $\mathrm{NH}^{4+}$ in soil leaching solution reacts with hypochlorite and phenol in strong alkaline medium to form water-soluble dye indophenol blue. The content of ammonium nitrogen $\left(\mathrm{NH}^{4+}-\mathrm{N}\right)$ can be determined by colorimetry (Zhao Jie et al., 2011).

\section{(2) Microbial biomass carbon}

The content of microbial biomass carbon (MBC) was determined by fumigation of the sample with $\mathrm{CHCl}_{3}$ and extraction with $0.5 \mathrm{~mol} \cdot \mathrm{L}-1 \mathrm{~K}_{2} \mathrm{SO}_{4}$ (Vance, E.D et al., 1987).

\section{(3) Enzyme activity}

Catalase activity was determined by measuring the $\mathrm{O}_{2}$ absorbed by $\mathrm{KMnO}_{4}$ in the sample added with $\mathrm{H}_{2} \mathrm{O}_{2}$ solution (Rodr1' guez-Ka'bana and Truelove, 1982). The sucrase activity was determined by measuring glucose content after incubation for $24 \mathrm{~h}$ at $37{ }^{\circ} \mathrm{C}$ with sucrose as a substrate(Guan Songyin, 1986). The amylase activity was measured by colorimetry (Zhou Likai et al., 1980), and it was determined by measuring the amount of glucose produced during hydrolysis. For the determination of urease activity (Guan Songyin, 1986), first one $5 \mathrm{~g}$ soil sample was put into a $100 \mathrm{ml}$ quantificational carafe, then add $5 \mathrm{ml}$ of $10 \%$ urease solution and $10 \mathrm{ml}$ of citrate buffer ( $\mathrm{pH} 6.7$ ), put the quantificational carafe into incubator for $24 \mathrm{~h}$ at $37{ }^{\circ} \mathrm{C}$. Finally, the released ammonium was determined colorimetrically at $578 \mathrm{~nm}$ using Indophenol reagent.

\section{Statistical analysis}

The processing software (Excel 2010, SPSS 19.0 and CANOCO 4.5) were used to analyze the integrated data. One-way ANOVA method was used to analyze the differences of soil microbial biomass carbon, soil physical, chemical properties and soil enzyme activities in different flooding degrees. The two-way ANOVA method was used to analyze the degree of flooding and the depth of soil layer, and their interaction effects on soil microbial biomass carbon, soil basic physical and chemical properties and soil enzyme activity were discussed. The effects of soil physicochemical properties and microbial biomass carbon on soil enzyme activity were analyzed by RDA sorting. It should be noted that the factors significantly related to soil enzyme activities need to be selected by Monte Carlo analysis before the redundancy analysis. The T-value double sequence diagram of CANOCO can also be used to analyze the single environmental factor affecting soil enzyme activity. 
158 Results

159 Soil physical and chemical properties

160 The same flooding conditions, the soil physical and chemical properties of soil layers with 161 different depths have certain differences (Table 1). Except for the PAW, the content of soil 162 organic carbon in the DMW and CEW was obviously different among the three soil layers. The 163 content of the SOC of the $0 \sim 10 \mathrm{~cm}$ soil layer of the CEW was significantly higher than that in $16410 \sim 20 \mathrm{~cm}, 20 \sim 30 \mathrm{~cm}$ and $30 \sim 40 \mathrm{~cm}$ soil layers, while that in the $0 \sim 10 \mathrm{~cm}$ and the $10 \sim 20 \mathrm{~cm}$ soil 165 layer of the DMW was significantly higher than that in the $20 \sim 30 \mathrm{~cm}$ and $30 \sim 40 \mathrm{~cm}$ soil layers.

166 For total phosphorus (TP), there were no significant differences between the DMW and 167 PAW in the three soil layers, and the TP content of the CEW decreased gradually with the 168 increase of soil depth. In terms of easily oxidized organic carbon (EOC), there were no 169 significant differences between the CEW and PAW in the three soil layers. The EOC content in $170 \quad 0 \sim 10 \mathrm{~cm}$ soil layer was the highest, while that in $30 \sim 40 \mathrm{~cm}$ soil layer was the lowest in the 171 DMW. The content of DOC in wetlands under three flooding conditions showed a decreasing 172 trend with the increase of soil depth.

173 Two-way ANOVA shows that except $\mathrm{NH}^{4+}-\mathrm{N}$, different flooding conditions and soil layers 174 have significant effects on the soil physical and chemical properties (Table 2). Among them, the 175 effect of flooding conditions on the physical and chemical properties of soil was greater than that 176 of soil depth. Only the $F$ value of TP in different soil depths was higher than that of $F$ value in 177 different flooding conditions, indicating that different soil conditions had a stronger effect on TP 178 content. At the same time, TP and SOC are also significantly affected by the interaction between 179 different flooding conditions and the soil depth, but the interaction has no significant effect on 180 EOC, DOC and $\mathrm{NH}^{4+}-\mathrm{N}$. Different flooding conditions in the same soil layer have different 181 effects on the soil physical and chemical properties (Table 1). By comparing the average values 182 in (Table 1), showed that the contents of TP, DOC and NH4+-N in wetlands with different 183 flooding conditions are PAW > CEW > DMW; the EOC content in wetlands with different 184 flooding conditions is DMW > CEW > PAW. And the SOC content in the CEW and DMW was 185 significantly higher than that in the PAW.

186

187

188

189

190

191

192

193

194

195

196

\section{Table 1}

\section{Table 2}

\section{Soil microbial biomass carbon}

There were differences in soil microbial biomass carbon at different soil depths under the same flooding conditions (Figure 2). The MBC content in $0 \sim 10 \mathrm{~cm}$ and $10 \sim 20 \mathrm{~cm}$ soil layers of the DMW and the CEW was significantly higher than that in $20 \sim 30 \mathrm{~cm}$ and $30 \sim 40 \mathrm{~cm}$ soil layers; the MBC content in $0 \sim 10 \mathrm{~cm}$ soil layers of the PAW was significantly higher than that in $30 \sim 40$ 
197

198

199

200

201

202

203

204

205

206

207

208

209

210

211

212

213

214

215

216

217

218

219

220

221

222

223

224

225

226

227

228

229

230

231

232

233

234

235

236

$\mathrm{cm}$ soil layers. The $\mathrm{MBC}$ in the wetland with three flooding conditions showed a trend of decreasing with the increase of soil depth.

The results of two-way ANOVA showed that different flooding conditions and soil layers had significant effects on soil microbial biomass carbon, and the interaction between them also significantly affected soil microbial biomass carbon (Table 3). The content of MBC decreased gradually with the increase of flooding degree. The $F$ value of MBC in different soil layers is far greater than that in different flooding conditions, which indicates that different soil depth has a deeper impact on the MBC than the flooding condition. The soil depth is indeed one of the important factors affecting the change of MBC content.

\section{Figure.2}

\section{Table 3}

\section{Differences of soil enzyme activities}

The activities of enzymes in different soil layers are different (Table 4). For the sucrose, the sucrase activity of wetlands with three flooding degrees decreased significantly with the increase of soil depth. Among them, the sucrase activity of $0-10 \mathrm{~cm}$ and $10 \sim 20 \mathrm{~cm}$ soil layers in the DMW and CEW was significantly higher than that of $20 \sim 30 \mathrm{~cm}$ and $30 \sim 40 \mathrm{~cm}$ soil layers; the sucrase activity of $0 \sim 10 \mathrm{~cm}$ soil layers in the PAW was significantly higher than that of 10 20 $\mathrm{cm}, 20 \sim 30 \mathrm{~cm}$ and $30 \sim 40 \mathrm{~cm}$ soil layers. There was no significant difference in the catalase activity between the DMW and PAW, but the catalase activity decreased with the increase of soil depth in the CEW. The amylase activity of the different soil layers was not significantly different in the PAW; the amylase activity in the DMW decreased at first and then increased with the increase of soil depth; the amylase activity in the CEW decreased with the increase of soil depth, and the amylase activity in $0-10 \mathrm{~cm}$ soil layer was the strongest. There was no significant difference in the urease activity among the three wetlands of flooding conditions.

According to Two-way ANOVA of flooding conditions and soil depth on soil enzyme activity (Table 5). Except the sucrase, the soil depth had no significant effect on other soil enzyme activities. Different flooding conditions have significant effects on the activities of the sucrase and amylase. The $F$ values of sucrase, amylase and urease activities in different flooding conditions were higher than those in different soil depths, which indicated that the effects of different flooding conditions on soil enzyme activities were greater than those at different soil depths, and flooding conditions were one of the important factors affecting soil enzyme activities. According to the average comparison in Table 4, the activities of sucrase and urease decreased gradually with the increase of flooding degree. Among them, the activities of sucrase in the CEW significantly decreased by $4.91 \%$ compared with the DMW, and the activities of sucrase in the PAW significantly decreased by $46.04 \%$ compared with the CEW.

Although the flooding conditions had no significant effect on the catalase activity in $0 \sim 10$ $\mathrm{cm}, 10 \sim 20 \mathrm{~cm}$ and $20 \sim 30 \mathrm{~cm}$ soil layers, the effects of different flooding conditions were 
237

238

239

240

241

242

243

244

245

246

247

248

249

250

251

252

253

254

255

256

257

258

259

260

261

262

263

264

265

266

267

268

269

270

271

272

273

274

275

276

extremely significant on the catalase activity in $30 \sim 40 \mathrm{~cm}$ soil layers. As far as the catalase activity in 30 40 cm soil layers was concerned, the DMW was significantly reduced by $18.45 \%$ compared with the CEW, and the CEW was significantly reduced by $33.20 \%$ compared with the PAW. The activities of sucrase and amylase in the DMW and CEW were significantly higher than those in the PAW, while the catalase activity was the highest in the CEW.

\section{Table 4}

\section{Table 5}

\section{Correlation analysis between soil enzyme activity and soil physical-chemical factors, microbial biomass carbon}

Redundancy analysis (RDA) was used to analyze the relationship between soil physical and chemical factors, microbial biomass carbon and soil enzyme activities in wetlands under different flooding conditions (Fig. 3). The results showed that the first two sorting axis together explained $52.6 \%$ of the change of soil enzyme activity, of which the contribution rate of the first sorting axis (RDA 1) was $47.6 \%$ and that of the second sorting axis (RDA 2) was 5\%. This indicated that most of the information between soil physical and chemical factors, microbial biomass carbon and soil enzyme activities could be reflected by these two axes, and was mainly determined by the first sorting axis. According to the redundancy analysis (Fig. 3), the arrow lines of SOC, DOC and TP are the longest, which together with the importance sorting results of Table 6 shows that SOC, DOC, TP and MBC can explain the changes of soil enzyme activities very well. The angles are small and the directions are the same between SOC and the sucrose, TP and catalase, which indicates that there are significant positive effects between SOC and the sucrase activity, TP and the catalase activity. SOC may be the dominant factor affecting the sucrase activity in Ili Valley, and TP is an important factor affecting the catalase activity.

A single environmental factor analysis was carried out for the environmental factors affecting soil enzyme activity by using the T-value double-sequence diagram of CANOCO 4.5 (Fig. 4). As shown in (Fig. 4A), the arrows of sucrase, urease and amylase all fall on the solid line circle of SOC, indicating that SOC has a significant positive correlation with the sucrase, urease and amylase activities, that is to say, the activities of sucrase, urease and amylase increase with the increase of SOC content. The arrow of catalase passes through the solid line circle of SOC, which shows that there is a positive correlation between SOC and CAT. (Fig. 4B) shows that four soil enzymes pass through the solid line circle of DOC, which indicates that there are a positive correlation between DOC and the activities of the four soil enzymes. (Fig. 4C) shows that most of the four soil enzymes fall outside the solid line circle and dotted line circle of $\mathrm{NH}^{4+}$ $\mathrm{N}$, indicating that there was no significant relationship between $\mathrm{NH}^{4+}-\mathrm{N}$ and the activities of the four soil enzymes.

Different environmental factors have different effects on soil enzyme activity (Table 6). The effects of different environmental factors on soil enzyme activities were $\mathrm{SOC}>\mathrm{DOC}>\mathrm{TP}>$ 
$277 \mathrm{MBC}>\mathrm{NH}^{4+}-\mathrm{N}>$ EOC. Among them, the effects of SOC, DOC, TP and MBC were significant 278 on soil enzyme activity, especially the effect of SOC on soil enzyme activity was extremely 279 significant. And SOC had the greatest effect on soil enzyme activity, accounting for $45 \%$ of the 280 total explanations $(F=27.82, p<0.01)$. The effects of $\mathrm{NH}^{4+}-\mathrm{N}$ and EOC were not significant on 281 soil enzyme activity $(p>0.05)$.

282

283

284

285

286

287

288

289

290

291

292

293

294

295

296

297

298

299

300

301

302

303

304

305

306

307

308

309

310

311

312

313

314

315

\section{Figure.3}

Table 6

\section{Figure.4}

\section{Discussion}

\section{Effects of different flooding conditions on soil enzyme activities}

Soil enzyme is a kind of proteins with special catalytic ability, which mainly comes from the decomposition of soil microorganisms, animal and plant secretions and residues (Guan Songyin, 1986). Soil moisture has a significant correlation with soil microbial activity and type, and different water conditions will directly affect the existence and activity of soil enzyme activity (Wan Zhongmei et al., 2005). It indicates that the degree of flooding did significantly affect the activity of soil enzymes. The results showed that the activities of sucrase and amylase were closely related to the degree of flooding, and decreased gradually with the increase of flooding degree (Wan Zhongmei et al., 2008; Zhou Xiaoming, 2018), which was consistent with the effect of flooding degree on sucrase and amylase activities, and the activities of sucrase and amylase in the rarely flooded and seasonal flooded wetlands were significantly higher than those in the long-term flooded wetlands. The phenomenon may be due to the increase of soil moisture, which leads to the decrease of soil permeability, restricts the growth of soil microorganisms, greatly slows down the decomposition of soil humus, and thus reduces the activity of soil enzymes. Studies have shown that soil moisture can affect soil microbial biomass by changing soil oxygen content (Rousk J et al., 2009). Therefore, it is also possible that in an environment with sufficient substrate and moist soil, increasing soil water will affect the availability of oxygen, thus affecting the growth of soil microorganisms and plant roots, resulting in the decrease of enzyme activity (Guenet et al., 2012).

In this study, although there is no significant correlation between flooding conditions and catalase, urease activity, as a whole, urease activity in very few flooded wetlands is much higher than that in perennial flooded wetlands, which may be because the deeper the soil layer in the wetland, the less the water content, the more conducive to the accumulation of soil organic matter and the improvement of enzyme activity. This is similar to the results of other researchers (Xu Jingjing et al., 2017). In this study, the catalase activity did not change significantly with the increase of the water content, which was consistent with the result that the catalase activity did 
316 not change significantly with the water gradient in non-rhizosphere soil (Tian Youhua et al., 317 2012).

318

\section{Effects of microbial biomass carbon and soil physical-chemical properties on soil enzyme} activities

Soil microbial biomass is an essential indicator for soil quality. On the one hand, it is highly sensitive and reflects small changes in soil before total carbon changes (Powlson D S, Brookes $\mathrm{P}$ the energy cycle (Doran JW., 1994). Previous studies have shown that the carbon contents of soil microbial biomass and soil enzyme activities in the treatment of underwater are higher than those in the treatment of natural bareness (Liu Yajun et al., 2017). (Table 6) shows that soil microbial biomass carbon is significantly correlated with soil enzyme activity, which is closely related to soil microbial biomass carbon and soil enzyme activity obtained by the predecessors. With the change of water gradient, soil enzyme activity is positively correlated with microbial biomass carbon (Wan Zhongmei et al., 2008). This is significantly related to the microbial biomass carbon and soil enzyme activity in this study, and the results are consistent with the law of decrease with the increase of water content (Table 6). This phenomenon is due to the fact that the soil aeration of rarely flooded wetlands is good, the vegetation grows luxuriantly, accelerates the decomposition of soil humus, provides a large number of carbon sources for the metabolism process of soil microorganisms, and leads to the increase of microbial biomass carbon (Jia G et al., 2005).

There was a certain relationship between soil organic carbon and soil enzyme activity (Wan Zhongmei et al., 2009). Soil organic matter is the main source of enzyme substrate, and the content of organic matter greatly affects the activity of soil enzyme. It can be seen from table 4 and showed that the activities of sucrase and amylase basically decrease with the increase of soil depth. This may be because plant roots are mostly concentrated on the surface of the soil. Vigorous root activity promotes the turnover of litter on the ground. The high content of organic matter in the soil leads to the increase of the respiration intensity of microorganisms, which is convenient for the reproduction of microorganisms, so that the higher soil enzyme activity is accumulated on the surface of the soil (Wan Zhongmei et al., 2008). It can be seen from Figure 3 that there is a significant positive correlation between soil organic carbon and sucrase, urease and amylase activities; there is a positive correlation between soil oxidizable organic carbon and sucrase, urease, catalase and amylase activities. This shows that most of the soil enzymes are sensitive to the change of soil active organic carbon composition, which is consistent with the previous research results (Xiao Ye et al., 2015). The soil organic matter in the degraded wetland of Napa sea in Northwest China changed from original swamp to swamp grassland, the cultivated land decreased gradually, and the activity of soil enzyme showed the same trend (Lu Mei et al., 2004). These results indicate that the soil enzyme activity is closely related to soil nutrients such as soil organic matter, and the change of soil enzyme activity can better reflect the degree of soil degradation. 
356

357

358

359

360

361

362

363

364

365

366

367

368

369

370

371

372

373

374

375

376

377

378

379

380

381

382

383

384

385

386

387

388

389

390

391

392

393

394

395

In this study, total phosphorus has a significant positive effect on the activities of four soil enzymes, and has the strongest correlation with the activities of catalase, which can better explain the changes of catalase activity, indicating that total phosphorus is the main factor affecting the activities of urease, catalase and sucrase through direct or indirect effects (Liu Guang shen et al., 2003). Previous studies have shown that the relationship between ammonium nitrogen and soil enzyme activity is not significant, and with the increase of soil depth, it first decreases and then increases (Xu Jing et al., 2017). The content of oxidized organic carbon in different wetland types decreased with the increase of soil depth (Xiao Ye et al., 2015). This is similar to the conclusion that the relationship between ammonium nitrogen, easily oxidized organic carbon and soil enzyme activity is not significant, and decreases with the increase of soil depth. This may be because the increase of water content can adjust the physical structure of soil, improve the effectiveness of soil nutrients, and facilitate the transfer of easily oxidized organic carbon and ammonium nitrogen in the soil (Wang Jie et al., 2014). It can be seen that the decrease of wetland water will lead to the loss of soil nutrients, which will cause a large area of wetland degradation.

\section{Conclusions}

The results show that soil organic carbon (SOC), dissolved organic carbon (DOC) and total phosphorus (TP) had significant effects on soil enzyme activity in wetland, while ammonium nitrogen (NH4+-N), easily oxidized organic carbon (EOC) and microbial biomass carbon (MBC) had no significant effects on soil enzyme activity. Among them, the correlation between soil organic carbon and the sucrase activity, total phosphorus and the catalase activity were the strongest, indicating that soil organic carbon is the main factor affecting sucrase activity, and total phosphorus is an important factor affecting catalase activity. Soil organic carbon had a significant positive correlation with sucrase, urease and amylase activity, but had a slight influence on catalase activity. Dissolved organic carbon had a positive correlation with four soil enzyme activities. It can be seen that the activity of soil enzyme in wetland is related closely to soil organic carbon and dissolved organic carbon.

Compared with the soil enzyme activities, it was found that the activities of sucrase and urease in wetland were in the order of rarely flooded wetlands $>$ seasonal flooded wetlands $>$ long-term flooded wetlands with the increase of flooding degree. The activity of amylase in rarely flooded wetland and seasonal flooded wetlands was significantly higher than that in longterm flooded wetlands. The activity of catalase in seasonal flooded wetlands was the highest. All of these indicate that the humid environment will inhibit the survival of plants and microorganisms in the soil, hinder the decomposition of organic matter, and lead to the decrease of enzyme activity. In conclusion, the soil enzyme activity is closely related to soil nutrients such as soil organic matter and water, and the change of soil enzyme activity can better reflect the degree of soil degradation. 
396

397

398

399

400

401

402

403

404

405

406

407

408

409

410

411

412

413

414

415

416

417

418

419

420

421

422

423

424

425

426

427

428

429

430

431

432

433

434

435

\section{Acknowledgements}

The author would like to thank Dr. Cui Dong, Dr. NijatKasim and Dr. Yang Haijun for his suggestions on sample collection in the early experimental stage, as well as for the revision and supplement of the manuscript. Thanks for the collection of materials by San Sancai, Gu Gie and Niu Mengmeng, and the map of the wetland sampling sites made by Dr Yan Junjie. Thank Dr. nijatkasim for his help on language issues in the manuscript. Thanks to the support of Tianshan Youth Program, a special talent program in Xinjiang Uygur Autonomous region (Fund number: 2018Q076).

\section{References}

Jenkinson D S, Adams D E, Wild A. 1991. Model estimates of $\mathrm{CO}_{2}$ emissions from soil in response to global warmin. Nature 351:304-306 DOI 10.1038/351304a0.

Garken Jumaken ette, Zhang Zhiping, Li Guihua, Duman ashanbayi, Guan Wei. 2018. Distribution characteristics and change analysis of wetland resources in Ili Valley (China Section) of Xinjiang. Transactions of Oceanology and Limnology (6):69-74 DOI 10.13984/j.cnki.cn37-1141.2018.06.010.

Lu Xiaoyi, He Chiquan. 2004. Current situation of wetland and its ecological restoration in China. Science 56 (3):29-32 DOI 10.3969/j.issn.0368-6396.2004.03.008.

Meng Xianmin. 1999. Wetlands and global environmental change. Geographic Science 19 (5): 385-391 DOI 10.3969/j.issn.1000-0690.1999.05.001.

Tan Xuejie, Zhao Xinsheng. 2006. Spatial distribution and ecological adaptation of wetland vegetation under water depth gradient. Chinese Journal of Ecology 25 (12):1460-1464.

Liu Yajun, Wu Juan, Zou Feng, Han Lili, Wu Lan. 2017.Response of soil microbial and enzyme characteristics to water gradient in ashed wetland of Poyang Lake. Wetland Science 15(2): 269-275 DOI 10.13248/j.cnki.wetlandsci.2017.02.016.

Garken Jumaken ette, Milligan. 2014. Wetland protection and management in Ili River Basin of Xinjiang. Wetland Science and Management 10 (3):43-45.

Wan Zhongmei, Song Changchun, Yang Guisheng, Huang Jingyu, Wang Lili, Li Yingchen. 2009. Characteristics of soil active organic carbon components and their relationship with soil enzyme activities in wetland of SanJiang Plain. Acta Scientiae Circumstantiae 29 (2):406-412 DOI 10.13671/j.hjkxxb.2009.02.030.

Chen Yanxin, Geng Yuqing, Huang Jin, Cui Xueqing, Hou Meng. 2019.Differences of soil enzyme activities and their influencing factors under different flooding conditions in bird island area of Qinghai Lake. Chinese Journal of Ecology 38 (03):735-743 DOI 0.13292/j.1000-4890.201903.011.

Xiao Ye, Huang Zhigang, Wu Haitao, Lv Xianguo. 2015. The composition and content of soil active organic carbon in different types of wetlands in Sanjiang Plain. Acta Ecologica Sinica 35 (23):7625-7633 DOI 10.5846/stxb201405060894.

Lu Rukun. 1999. Methods for chemical analysis of soil agriculture. Beijing: China Agricultural Science and Technology Press. 
436

437

438

439

440

441

442

443

444

445

446

447

448

449

450

451

452

453

454

455

456

457

458

459

460

461

462

463

464

465

466

467

468

469

470

471

472

473

474

Blair G J, Lefroy RDB, Lisle L. 1995. Soil carbon fractions based on their degree of oxidation, and the development of a carbon management index foragricultural systems. Australian Journal of Agricultural Research 46(7):1459-1466 DOI 10.1071/AR9951459.

Zhan Xinhua, Zhou Lixiang. 2002. Colorimetric determination of water-soluble organic carbon in soil solution and water. China Environmental Science 22 (5):433-437.

Zhao Jie, Wang Li. 2011.Study on the feasibility of rapid determination of nitrate and ammonium nitrogen by Spectrophotometry. Modern Agricultural Sciences and Technology 6:42-42 DOI 10.3969/j.issn.1007-5739.2011.06.018.

Vance E D, Brookes P C, Jenkinson D. 1987. An extraction method for measuring microbial biomass carbon. Soil Biology and Biochemistry 19 (6):703-707 DOI 10.1016/00380717(87)90052-6.

Rodríguez-Kábana R, Truelove B. 1982. Effects of crop rotation and fertilization on catalase activity in a soil of the south-eastern United States. Plant and Soil 69(1):97-104 DOI 10.1007/BF02185708.

Guan Songyin. 1986. Soil enzymes and their research methods. Beijing: China Agriculture Press.

Wan Zhongmei, Wu Jinggui. 2005. Research progress on factors affecting soil enzyme activity. Journal of Northwest Agriculture and Forestry University 33 (6):87-91 DOI 10.13207/j.cnki.jnwafu.2005.06.019.

Wan Zhongmei, Song Changchun, Guo Yuedong, Wang Li, Huang Jingyu.2008.Response of soil enzyme activity and active organic carbon components to water gradient in Carex tomentosa wetland. Acta Ecologica Sinica 28 (12):5980-5986 DOI 10.3321/j.issn:10000933.2008.12.025.

Zhou Xiaoming. 2018. Study on soil microbial diversity and soil enzyme activity in Wetlands of the Yellow River Delta. MSC. Thesis, Qufu Normal University.

Rousk J, Brookes P C, Erland Bååth. 2009.Contrasting soil pH effects on fungal and bacterial growth suggest functional redundancy in carbon mineralization. Applied and environmental microbiology 75(6): 1589-1596 DOI 10.1128/AEM.02775-08.

Guenet B, Lenhart K, Leloup J, Giusti-Miller S, Pouteau V, Mora P, Nunan N, Abbadie L. 2012. The impact of long-term $\mathrm{CO}_{2}$ enrichment and moisture levels on soil microbial community structure and enzyme activities. Geo-derma 170:331-336 DOI 10.1016/j.geoderma.2011.12.002.

Xu Jingjing, Liu Suiyanhao, Zhu Xinping, Jia Hongtao, Xu Xiaolong, Sun Tao, Gulizhar Aimduli. 2017. Differences of soil microorganisms and enzyme activities in different water gradients of Swan Lake Alpine Wetland in Bayinbrook. Journal of Xinjiang Agricultural University 40 (5):337-344.

Tian Youhua, Guang Hui, Yang Xiaodong, Xie Hui, Sun Lijun. 2012.Effects of water and salt stress on enzyme activities in plant rhizosphere of arid regions. Journal of Arid Land Resources and Environment 26(3):156-163 DOI 10.13448/j.cnki.jalre.2012.03.020. 
475

476

477

478

479

480

481

482

483

484

485

486

487

488

489

490

491

492

493

494

495

496

497

498

499

500

501

502

503

504

505

506

507

508

509

510

511

512

513

514

Powlson D S, Brookes P C, Christensen B T. 1987. Measurement of microbial biomass provides an early indication of changes in total soil organic matter due to straw incorporation. Soil Biochemistry 19(2):159-164 DOI 10.1016/0038-0717(87)90076-9.

Doran J W. 1994. Defining soil Quality for a Sustainable Environment. Soil of America Special Publication 66:3-234.

Jia Guomei, Jing Cao, Wang Chunyan, Wang Gang. 2005. Microbial biomass and nutrients in soil at the different stages of secondary forest succession in Ziwulin. Northwest China. Forest Ecology and Management 217:117-125 DOI 10.1016/j.foreco.2005.05.055.

Wan Zhongmei, Song Changchun. 2008. Distribution characteristics of soil enzyme activity and its relationship with characterization indexes of active organic carbon. Wetland Science 6(2):249-256 DOI 10.13248/j.cnki.wetlandsci.2008.02.022.

Liu Guangshen, Xu Dongmei, Xu Zhongjian, Wang Hongyu, Liu Weiping. 2003. The relationship between soil hydrolase activity and soil properties was studied by path analysis. Acta Pedologica Sinica 40 (5):756-762 DOI 10.11766/trxb200111090518.

Lu Mei, Tian Kun, Chen Yuhui, Chang Fenglai, Mo Jianfeng. 2004. Nutrient and enzyme activities of degraded soil in the plateau wetland Napahai. Journal of Southwest Forestry University 24 (1):34-37 DOI 10.3969/j.issn.2095-1914.2004.01.009.

Wang Jie, Li Gang, Xiu Weiming, Song Xiaolong, Zhao Jianning, Yang Dianlin. 2014. Effects of nitrogen and water on soil enzyme activity and microbial biomass carbon and nitrogen in Stipa baicalensis grassland. Journal of agricultural resources and environment (3): 237-245.

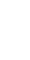

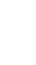

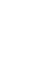


515

516

517

518

519

520

521

522

523

524

525

526

527

528

529

530

531

532

533

534

535

536

537

538

539

540

541

542

543

544

545

546

547

548

549

550

551

552

553

554

555

556

557

\section{Figure Interpretation}

\section{Figure.1}

Diagram of wetland sampling point in Ili Valley.

DMW: Ditch millet wetland; CEW: Calamagrostis epigeios wetland; PAW: Phragmites australis wetland

\section{Figure.2}

Soil microbial biomass carbon content in wetland soil of different layers under different flooding conditions.

\section{Figure.3}

\section{Redundancy analysis of the effect of soil physical and chemical properties on soil enzyme activity}

The quadrant of arrow in the figure represents the positive and negative correlation between different factors and the sorting axis, the hollow arrow represents several soil enzymes, the solid arrow represents environmental variables, and the cosine value of corresponding angle represents the correlation between environmental variables and soil enzymes. With the smaller the cosine value, the greater the correlation. Solid line represents the factors significantly related to the soil enzyme activity $(p<0.05)$.

\section{Figure.4}

The T-value for a single factor influencing varied of soil enzyme activities in wetland.

The quadrant of the arrow in the figure represents the positive and negative correlation between different factors and the sorting axis. The arrow represents several soil enzymes, and the solid triangle represents environmental variables. 
558

559

560

561

562

563

564

565

566

567

568

569

570 


\section{Table 1 (on next page)}

Soilbasic physical and chemical properties of different soil thickness underdifferent flooding conditions.

The values are average (standard error). The different letters of the same column data represent significant differences among different soil layers of the same wetland $(p<0.05)$. Table 4 is the same. 
1 Table 1

2 Soil basic physical and chemical properties of different soil thickness under different flooding conditions.

\begin{tabular}{|c|c|c|c|c|c|c|}
\hline $\begin{array}{c}\text { Wetland } \\
\text { Type }\end{array}$ & $\begin{array}{c}\text { Soil Layer } \\
(\mathrm{cm})\end{array}$ & $\begin{array}{c}\text { SOC } \\
\left(g \bullet k g^{-1}\right)\end{array}$ & $\begin{array}{c}\mathrm{TP} \\
\left(g \bullet k g^{-1}\right)\end{array}$ & $\begin{array}{c}\text { EOC } \\
\left(\mathrm{mg} \bullet \mathrm{kg}^{-1}\right)\end{array}$ & $\begin{array}{c}\text { DOC } \\
\left(\mathrm{mg} \bullet \mathrm{kg}^{-1}\right)\end{array}$ & $\begin{array}{c}\mathrm{NH}_{4}^{+}-\mathrm{N} \\
\left(\mathrm{mg} \bullet \mathrm{kg}^{-1}\right)\end{array}$ \\
\hline \multirow{4}{*}{ DMW } & $0-10$ & $\begin{array}{c}27.17 \mathrm{a} \\
(7.02)\end{array}$ & $\begin{array}{l}8.15 \mathrm{a} \\
(0.57)\end{array}$ & $\begin{array}{l}7.39 \mathrm{a} \\
(0.95)\end{array}$ & $\begin{array}{c}219.30 \mathrm{a} \\
(3.53)\end{array}$ & $\begin{array}{l}6.99 \mathrm{a} \\
(0.25)\end{array}$ \\
\hline & $10-20$ & $\begin{array}{c}16.43 \mathrm{ab} \\
(6.42)\end{array}$ & $\begin{array}{l}7.35 \mathrm{a} \\
(0.50)\end{array}$ & $\begin{array}{l}4.11 b \\
(0.85)\end{array}$ & $\begin{array}{c}199.72 \mathrm{ab} \\
(5.87)\end{array}$ & $\begin{array}{l}6.68 \mathrm{a} \\
(0.34)\end{array}$ \\
\hline & $20-30$ & $\begin{array}{l}6.57 \mathrm{~b} \\
(2.29)\end{array}$ & $\begin{array}{l}6.61 \mathrm{a} \\
(0.67)\end{array}$ & $\begin{array}{l}4.63 \mathrm{~b} \\
(0.38)\end{array}$ & $\begin{array}{c}173.28 \mathrm{~b} \\
(6.42)\end{array}$ & $\begin{array}{l}6.59 \mathrm{a} \\
(0.31)\end{array}$ \\
\hline & $30-40$ & $\begin{array}{l}5.79 \mathrm{~b} \\
(1.98)\end{array}$ & $\begin{array}{l}6.29 \mathrm{a} \\
(0.50)\end{array}$ & $\begin{array}{l}3.48 \mathrm{~b} \\
(0.04)\end{array}$ & $\begin{array}{c}145.87 \mathrm{c} \\
(11.29)\end{array}$ & $\begin{array}{l}6.48 \mathrm{a} \\
(0.29)\end{array}$ \\
\hline \multirow{4}{*}{ CEW } & $0-10$ & $\begin{array}{l}31.37 \mathrm{a} \\
(11.01)\end{array}$ & $\begin{array}{l}8.30 \mathrm{a} \\
(0.06)\end{array}$ & $\begin{array}{l}6.15 \mathrm{a} \\
(1.68)\end{array}$ & $\begin{array}{c}241.81 \mathrm{a} \\
(4.27)\end{array}$ & $\begin{array}{l}7.20 \mathrm{a} \\
(0.20)\end{array}$ \\
\hline & $10-20$ & $\begin{array}{c}15.06 \mathrm{ab} \\
(6.89)\end{array}$ & $\begin{array}{c}7.85 \mathrm{ab} \\
(0.36)\end{array}$ & $\begin{array}{l}4.09 \mathrm{a} \\
(0.20)\end{array}$ & $\begin{array}{c}214.40 \mathrm{ab} \\
(2.94)\end{array}$ & $\begin{array}{l}6.95 \mathrm{a} \\
(0.10)\end{array}$ \\
\hline & $20-30$ & $\begin{array}{c}11.18 \mathrm{ab} \\
(7.50)\end{array}$ & $\begin{array}{l}7.23 \mathrm{~b} \\
(0.42)\end{array}$ & $\begin{array}{l}4.52 \mathrm{a} \\
(0.56)\end{array}$ & $\begin{array}{c}181.11 \mathrm{~b} \\
(6.42)\end{array}$ & $\begin{array}{l}6.78 \mathrm{a} \\
(0.08)\end{array}$ \\
\hline & $30-40$ & $\begin{array}{l}3.32 \mathrm{~b} \\
(0.29)\end{array}$ & $\begin{array}{l}7.20 \mathrm{~b} \\
(0.23)\end{array}$ & $\begin{array}{l}3.25 \mathrm{a} \\
(1.33)\end{array}$ & $\begin{array}{c}140.00 \mathrm{c} \\
(20.51)\end{array}$ & $\begin{array}{l}6.76 \mathrm{a} \\
(0.08)\end{array}$ \\
\hline \multirow{4}{*}{ PAW } & $0-10$ & $\begin{array}{c}11.66 \mathrm{a} \\
(5.21)\end{array}$ & $\begin{array}{l}8.72 \mathrm{a} \\
(0.64)\end{array}$ & $\begin{array}{l}5.07 \mathrm{a} \\
(3.00)\end{array}$ & $\begin{array}{c}256.50 \mathrm{a} \\
(36.38)\end{array}$ & $\begin{array}{l}7.22 \mathrm{a} \\
(0.25)\end{array}$ \\
\hline & $10-20$ & $\begin{array}{l}4.49 \mathrm{a} \\
(2.26)\end{array}$ & $\begin{array}{l}8.39 \mathrm{a} \\
(0.56)\end{array}$ & $\begin{array}{l}3.68 \mathrm{a} \\
(0.55)\end{array}$ & $\begin{array}{c}237.90 \mathrm{a} \\
(38.33)\end{array}$ & $\begin{array}{l}7.02 \mathrm{a} \\
(0.15)\end{array}$ \\
\hline & $20-30$ & $\begin{array}{l}1.66 \mathrm{a} \\
(0.49)\end{array}$ & $\begin{array}{l}7.88 \mathrm{a} \\
(0.88)\end{array}$ & $\begin{array}{l}3.15 \mathrm{a} \\
(0.79)\end{array}$ & $\begin{array}{c}206.57 \mathrm{a} \\
(33.46)\end{array}$ & $\begin{array}{l}6.97 \mathrm{a} \\
(0.24)\end{array}$ \\
\hline & $30-40$ & $\begin{array}{l}1.67 \mathrm{a} \\
(0.88)\end{array}$ & $\begin{array}{l}7.82 \mathrm{a} \\
(0.47)\end{array}$ & $\begin{array}{l}3.02 \mathrm{a} \\
(2.07)\end{array}$ & $\begin{array}{c}158.60 \mathrm{a} \\
(22.17)\end{array}$ & $\begin{array}{l}6.84 \mathrm{a} \\
(0.32)\end{array}$ \\
\hline
\end{tabular}

3 The values are average (standard error). The different letters of the same column data represent significant

4 differences among different soil layers of the same wetland $(p<0.05)$. Table 4 is the same.

5 


\section{Table 2 (on next page)}

A two-way ANOVA for theeffects of different flooding conditions and soil layers on soil basicphysicochemical properties . 
1 Table 2

2 A two-way ANOVA for the effects of different flooding conditions and soil layers on soil basic

3 physicochemical properties.

\begin{tabular}{ccccccc}
\hline $\begin{array}{c}\text { Influence } \\
\text { Factor }\end{array}$ & $\begin{array}{c}\mathrm{SOC} \\
\left(\mathrm{g} \bullet \mathrm{kg}^{-1}\right)\end{array}$ & $\begin{array}{c}\mathrm{TP} \\
\left(\mathrm{g} \bullet \mathrm{kg}^{-1}\right)\end{array}$ & $\begin{array}{c}\mathrm{EOC} \\
\left(\mathrm{mg} \bullet \mathrm{kg}^{-1}\right)\end{array}$ & $\begin{array}{c}\mathrm{DOC} \\
\left(\mathrm{mg} \bullet \mathrm{kg}^{-1}\right)\end{array}$ & $\begin{array}{c}\mathrm{NH}_{4}{ }^{+}-\mathrm{N} \\
\left(\mathrm{mg} \bullet \mathrm{kg}^{-1}\right)\end{array}$ \\
\hline \multirow{2}{*}{ Soil Layer } & $F$ & 4.29 & 4.40 & 0.50 & 2.02 & 1.30 \\
Flooding & $P$ & 0.03 & 0.00 & 0.00 & 0.00 & 0.29 \\
Conditions & $P$ & 7.70 & 3.38 & 1.72 & 10.87 & 3.06 \\
& $F$ & 0.00 & 0.02 & 0.01 & 0.00 & 0.05 \\
Interaction & $F$ & 0.55 & 0.34 & 0.45 & 0.13 & 0.28 \\
& $P$ & 0.03 & 0.02 & 0.84 & 0.99 & 0.94 \\
\hline
\end{tabular}

4 


\section{Table 3(on next page)}

A two-way ANOVA for theeffects of different flooding conditions and different soil layers on soilmicrobial biomass carbon . 
1 Table 3

2 A two-way ANOVA for the effects of different flooding conditions and different soil layers on soil

3 microbial biomass carbon.

\begin{tabular}{ccc}
\hline Influence Factor & & MBC \\
\hline \multirow{2}{*}{ Soil Layer } & $F$ & 2192.83 \\
& $P$ & 0.00 \\
Flooding & $F$ & 465.36 \\
Conditions & $P$ & 0.00 \\
Interaction & $F$ & 75.75 \\
& $P$ & 0.00 \\
\hline
\end{tabular}

4 


\section{Table 4(on next page)}

Soi lenzyme activities of different soil thickness under different floodingconditions . 


\section{Table 4}

2 Soil enzyme activities of different soil thickness under different flooding conditions.

\begin{tabular}{|c|c|c|c|c|c|}
\hline $\begin{array}{l}\text { Wetland } \\
\text { Type }\end{array}$ & $\begin{array}{l}\text { Soil Layer } \\
\text { (cm) }\end{array}$ & $\begin{array}{c}\text { Sucrase } \\
(\mathrm{mg} \cdot(\mathrm{g} \cdot 24 \mathrm{~h})-1)\end{array}$ & $\begin{array}{l}\text { Catalase } \\
(\mathrm{mg} / \mathrm{g})\end{array}$ & $\begin{array}{c}\text { Amylase } \\
(\mathrm{mgC} 6 \mathrm{H} 12 \mathrm{O} 6 /(\mathrm{g} * \mathrm{~h}))\end{array}$ & $\begin{array}{l}\text { Urease } \\
(\mathrm{mg} / \mathrm{g})\end{array}$ \\
\hline \multirow{4}{*}{ DMW } & $0-10$ & $\begin{array}{l}1.57 \mathrm{a} \\
(0.27)\end{array}$ & $\begin{array}{l}1.72 \mathrm{a} \\
(0.51)\end{array}$ & $\begin{array}{l}14.52 \mathrm{a} \\
(0.22)\end{array}$ & $\begin{array}{l}23.91 \mathrm{a} \\
(10.63)\end{array}$ \\
\hline & $10-20$ & $\begin{array}{l}1.43 \mathrm{a} \\
(0.31)\end{array}$ & $\begin{array}{l}1.90 \mathrm{a} \\
(0.30)\end{array}$ & $\begin{array}{l}6.60 \mathrm{~b} \\
(0.23)\end{array}$ & $\begin{array}{l}13.74 \mathrm{a} \\
(7.38)\end{array}$ \\
\hline & $20-30$ & $\begin{array}{c}0.93 \mathrm{ab} \\
(0.16)\end{array}$ & $\begin{array}{l}1.91 \mathrm{a} \\
(0.26)\end{array}$ & $\begin{array}{l}5.75 \mathrm{~b} \\
(0.51)\end{array}$ & $\begin{array}{l}12.01 \mathrm{a} \\
(7.01)\end{array}$ \\
\hline & $30-40$ & $\begin{array}{l}0.47 \mathrm{~b} \\
(0.08)\end{array}$ & $\begin{array}{l}2.16 \mathrm{a} \\
(0.05)\end{array}$ & $\begin{array}{l}6.47 \mathrm{~b} \\
(0.53)\end{array}$ & $\begin{array}{l}5.86 \mathrm{a} \\
(2.62)\end{array}$ \\
\hline \multirow{4}{*}{ CEW } & $0-10$ & $\begin{array}{l}2.19 \mathrm{a} \\
(0.24)\end{array}$ & $\begin{array}{l}2.10 \mathrm{a} \\
(0.02)\end{array}$ & $\begin{array}{l}13.29 \mathrm{a} \\
(3.41)\end{array}$ & $\begin{array}{l}20.04 \mathrm{a} \\
(12.13)\end{array}$ \\
\hline & $10-20$ & $\begin{array}{l}1.16 \mathrm{~b} \\
(0.36)\end{array}$ & $\begin{array}{l}2.03 \mathrm{a} \\
(0.06)\end{array}$ & $\begin{array}{l}8.76 \mathrm{ab} \\
(2.53)\end{array}$ & $\begin{array}{l}12.98 \mathrm{a} \\
(7.36)\end{array}$ \\
\hline & $20-30$ & $\begin{array}{l}0.44 \mathrm{c} \\
(0.03)\end{array}$ & $\begin{array}{l}1.96 \mathrm{a} \\
(0.05)\end{array}$ & $\begin{array}{l}5.84 \mathrm{~b} \\
(0.24)\end{array}$ & $\begin{array}{l}7.96 \mathrm{a} \\
(2.61)\end{array}$ \\
\hline & $30-40$ & $\begin{array}{l}0.40 \mathrm{c} \\
(0.03)\end{array}$ & $\begin{array}{l}1.76 \mathrm{~b} \\
(0.04)\end{array}$ & $\begin{array}{l}5.83 \mathrm{~b} \\
(0.59)\end{array}$ & $\begin{array}{l}7.23 \mathrm{a} \\
(2.43)\end{array}$ \\
\hline \multirow{4}{*}{ PAW } & $0-10$ & $\begin{array}{l}1.21 \mathrm{a} \\
(0.38)\end{array}$ & $\begin{array}{l}1.97 \mathrm{a} \\
(0.24)\end{array}$ & $\begin{array}{l}10.45 \mathrm{a} \\
(3.27)\end{array}$ & $\begin{array}{l}7.81 \mathrm{a} \\
(2.62)\end{array}$ \\
\hline & $10-20$ & $\begin{array}{l}0.39 \mathrm{~b} \\
(0.03)\end{array}$ & $\begin{array}{l}1.92 \mathrm{a} \\
(0.25)\end{array}$ & $\begin{array}{l}6.17 \mathrm{a} \\
(0.81)\end{array}$ & $\begin{array}{l}6.10 \mathrm{a} \\
(2.28)\end{array}$ \\
\hline & $20-30$ & $\begin{array}{l}0.34 \mathrm{~b} \\
(0.02)\end{array}$ & $\begin{array}{l}1.72 \mathrm{a} \\
(0.30)\end{array}$ & $\begin{array}{l}6.21 \mathrm{a} \\
(0.26)\end{array}$ & $\begin{array}{l}4.74 \mathrm{a} \\
(2.41)\end{array}$ \\
\hline & $30-40$ & $\begin{array}{l}0.32 \mathrm{~b} \\
(0.02)\end{array}$ & $\begin{array}{l}1.17 \mathrm{a} \\
(0.40)\end{array}$ & $\begin{array}{l}5.92 \mathrm{a} \\
(0.68)\end{array}$ & $\begin{array}{l}6.86 \mathrm{a} \\
(3.10)\end{array}$ \\
\hline
\end{tabular}

3 


\section{Table 5 (on next page)}

A two-way ANOVA for the effects of flooding conditions and soil layers on soil enzyme activities. 
1 Table 5

2 A two-way ANOVA for the effects of flooding conditions and soil layers on soil enzyme activities.

\begin{tabular}{cccccc}
\hline $\begin{array}{c}\text { Influence } \\
\text { Factor }\end{array}$ & & Sucrase & Catalase & Amylase & Urease \\
\hline \multirow{2}{*}{ Soil Layer } & $F$ & 7.78 & 1.25 & 0.74 & 1.58 \\
& $P$ & 0.03 & 0.30 & 0.49 & 0.23 \\
Flooding & $F$ & 21.08 & 0.60 & 12.13 & 1.69 \\
Conditions & $P$ & 0.00 & 0.62 & 0.00 & 0.20 \\
& $F$ & 2.18 & 1.11 & 0.59 & 0.35 \\
Interaction & $P$ & 0.04 & 0.38 & 0.74 & 0.90 \\
\hline
\end{tabular}

3

4 


\section{Table 6(on next page)}

Significance rank andsignificance test of soil physicochemical factors and microbial biomass carbonin explanation . 
1 Table 6

2 Significance rank and significance test of soil physicochemical factors and microbial biomass carbon in 3 explanation.

\begin{tabular}{ccccc}
\hline $\begin{array}{c}\text { environmental } \\
\text { Factor }\end{array}$ & $\begin{array}{c}\text { Sorting of } \\
\text { Importance }\end{array}$ & $\begin{array}{c}\text { Degree of } \\
\text { Interpretation }(\%)\end{array}$ & $\begin{array}{c}\text { Importance } \\
(F \text { value })\end{array}$ & $\begin{array}{c}\text { Significance } \\
(P \text { value })\end{array}$ \\
\hline SOC & 1 & 45 & 27.824 & 0.002 \\
DOC & 2 & 13.3 & 5.209 & 0.012 \\
$\mathrm{TP}$ & 3 & 8.9 & 3.337 & 0.032 \\
$\mathrm{MBC}$ & 4 & 5.1 & 2.728 & 0.050 \\
$\mathrm{NH}_{4}{ }^{+}-\mathrm{N}$ & 5 & 8.5 & 3.139 & 0.114 \\
$\mathrm{EOC}$ & 6 & 4.7 & 1.284 & 0.296 \\
\hline
\end{tabular}

4 
Figure 1

Diagram of wetland sampling point in Ili Valley

DMW: Ditch millet wetland; CEW: Calamagrostis epigeios wetland; PAW: Phragmites australis wetland

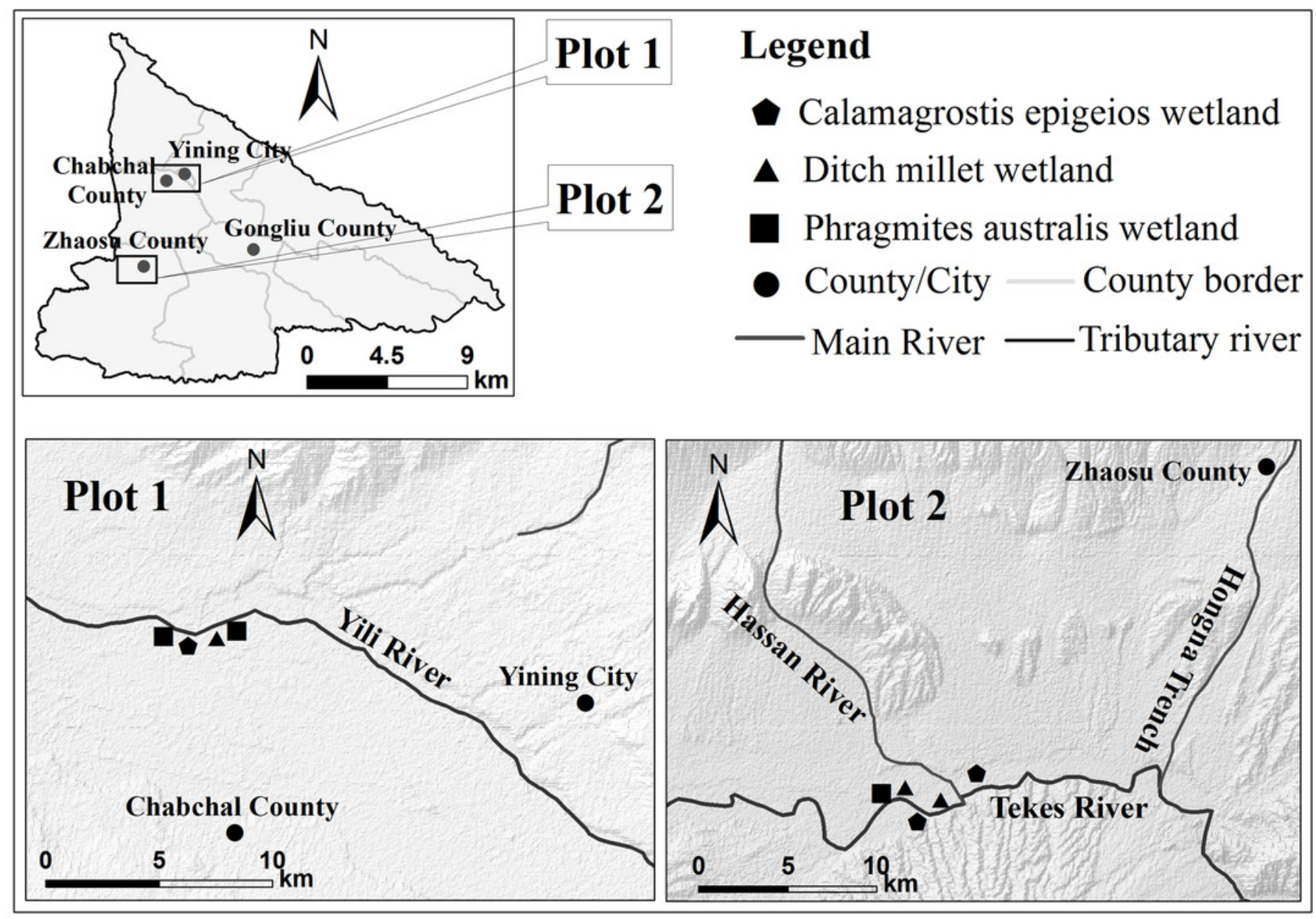


Figure 2

Soil microbial biomass carbon content in wetland soil of different layers under different flooding conditions.

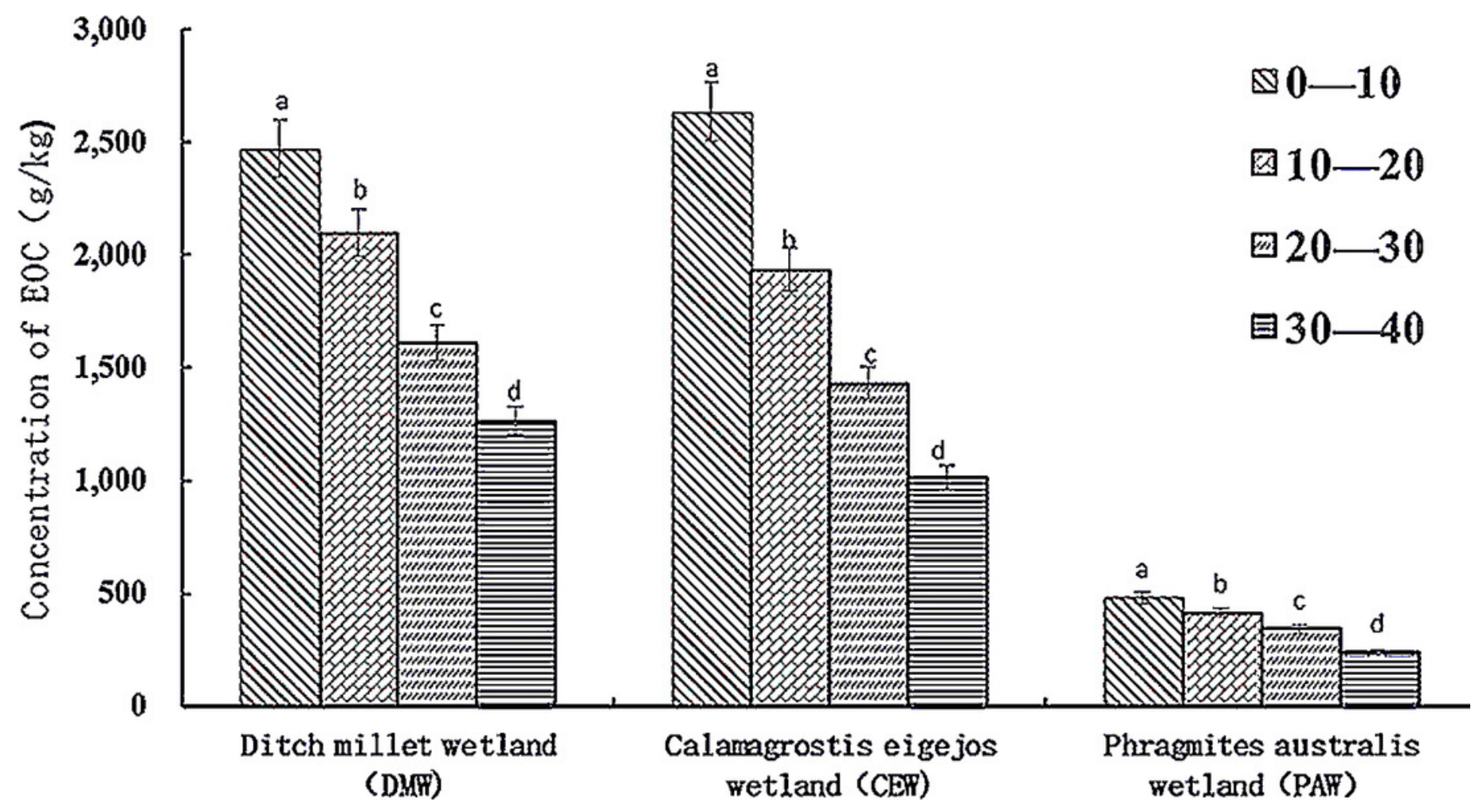




\section{Figure 3}

Redundancy analysis of the effect of soil physical and chemical properties on soil enzyme activity

The quadrant of arrow in the figure represents the positive and negative correlation between different factors and the sorting axis, the hollow arrow represents several soil enzymes, the solid arrow represents environmental variables, and the cosine value of corresponding angle represents the correlation between environmental variables and soil enzymes. With the smaller the cosine value, the greater the correlation. Solid line represents the factors significantly related to the soil enzyme activity $(p<0.05)$. 


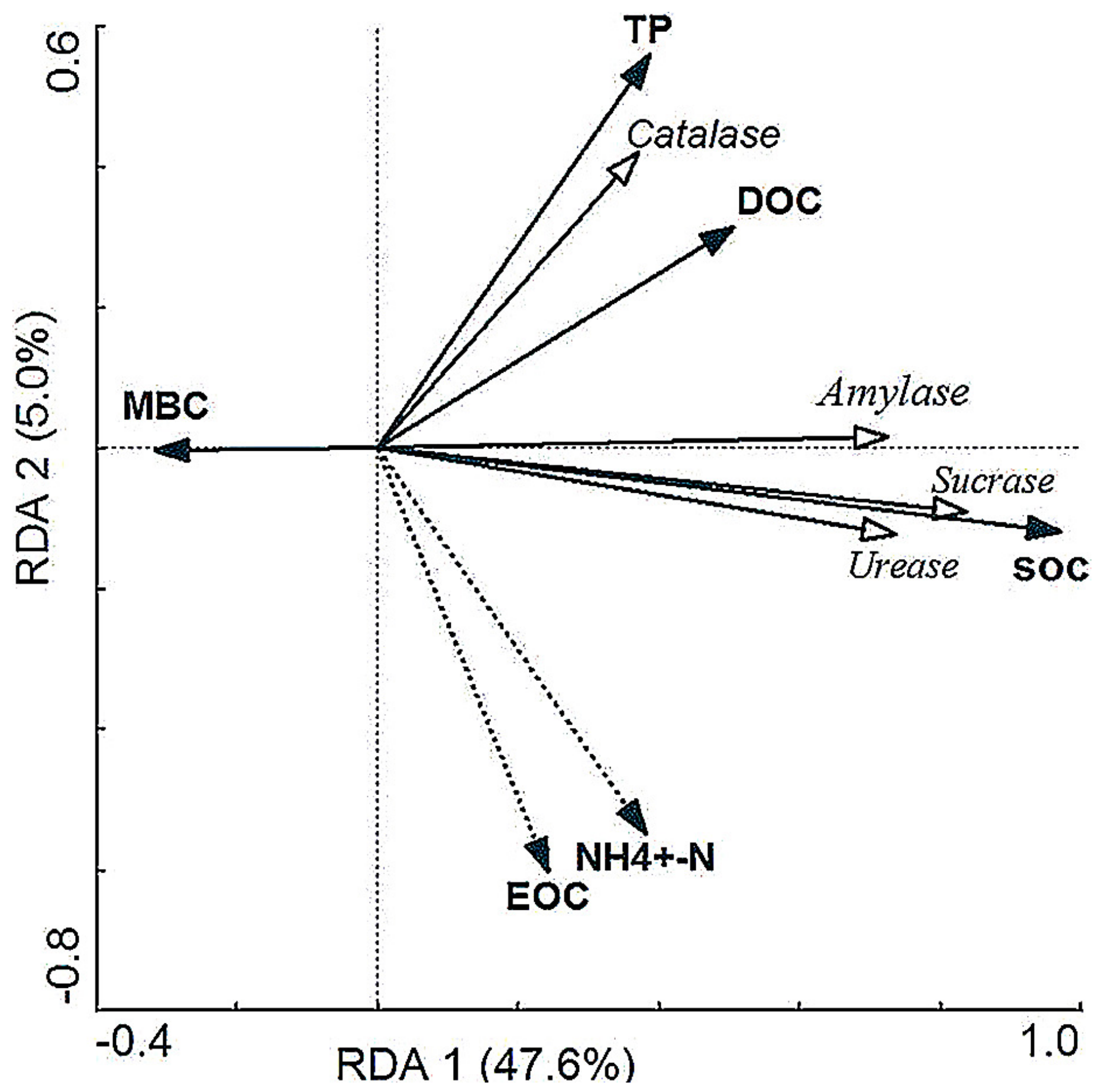


Figure 4

The T-value for a single factor influencing varied of soil enzyme activities in wetland.

The quadrant of the arrow in the figure represents the positive and negative correlation between different factors and the sorting axis. The arrow represents several soil enzymes, and the solid triangle represents environmental variables.
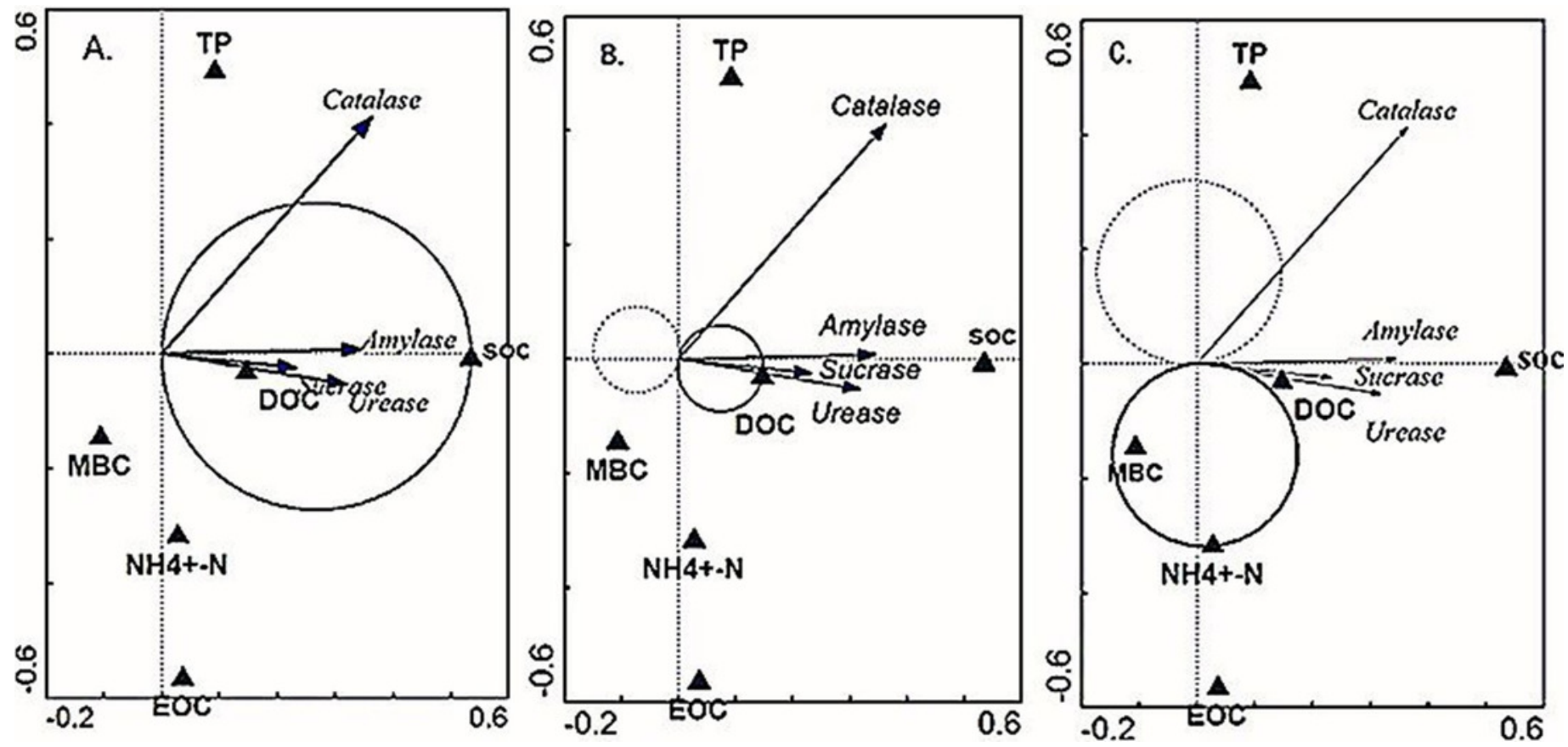